\title{
Deglacial biogenic opal peaks revealing enhanced Southern Ocean upwelling during the last $513 \mathrm{ka}$
}

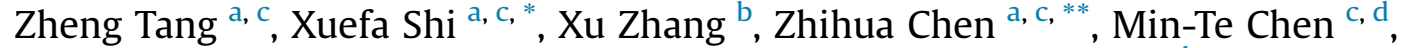 \\ Xiangqin Wang a , Haozhuang Wang a , Helin Liu ${ }^{a}$, Gerrit Lohmann ${ }^{\text {b }}$, Peiying Li ${ }^{\text {a, c }}$, \\ Shulan Ge ${ }^{\text {a, c }}$, Yuanhui Huang a, c \\ a Key Laboratory of Marine Sedimentology and Environmental Geology, First Institute of Oceanography, State Oceanic Administration, Qingdao, 266061, \\ China \\ ${ }^{\mathrm{b}}$ Alfred Wegener Institute Helmholtz Centre for Polar and Marine Research, Bremerhaven, D-27570, Germany \\ ${ }^{c}$ Laboratory for Marine Geology, Qingdao National Laboratory for Marine Science and Technology, Qingdao, 266061, China \\ d Institute of Applied Geosciences, Taiwan Ocean University, Keelung, 20224, China
}

\section{A R T I C L E I N F O}

\section{Article history:}

Received 31 July 2016

Received in revised form

7 September 2016

Accepted 12 September 2016

Available online $\mathrm{xxx}$

\section{Keywords:}

Southern ocean

Ventilation

Biogenic opal peaks

Glacial termination

\begin{abstract}
A B S T R A C T
Strength of Southern Ocean upwelling controls the exchange of carbon dioxide $\left(\mathrm{CO}_{2}\right)$ between deep ocean reservoirs and atmosphere, as well as the communication of dissolved silicon with the euphotic zone of the Southern Ocean. The silicon supply could limit diatom opal productivity in the high-latitudes of Southern Ocean and the subsequent burial of biogenic opal in underlying sediments. Here we report a record of biogenic opal export off the Prydz Bay south of the polar front of the Southern Ocean, indicating strengthened upwelling during the past five glacial terminations. In all five terminations $(\mathrm{I}-\mathrm{V})$, opal peaks occur in line with Northern Hemisphere summer insolation intensity as well as the existing IRDs, indicating that freshwater injection associated with retreat of the Northern Hemisphere ice sheets could be the cause of enhanced upwelling in the Southern Ocean during terminations. This could in turn promote $\mathrm{CO}_{2}$ outgassing, finally accelerating the completion of the terminations. In addition, the enhanced upwelling could export the Si-rich deep water to low latitudes via Antarctic Intermediate Water (AAIW) and Subantarctic Mode Water (SAMW), potentially leading to deglacial opal peaks in subtropical North Atlantic.
\end{abstract}

๑) 2016 Elsevier Ltd and INQUA. All rights reserved.

\section{Introduction}

To improve the understanding of future climate change under the increasing anthropogenic $\mathrm{CO}_{2}$ levels, a number of attempts have been made to interpret the close association between atmospheric $\mathrm{CO}_{2}$ and global temperature in the late Quaternary (Siegenthaler et al., 2005). It is known that no single source can account for the full amplitude of glacial-interglacial variability of atmospheric $\mathrm{CO}_{2}$ (Sigman and Boyle, 2000; Archer et al., 2000). Although multiple carbon sources may be involved (Köhler et al., 2005; Peacock et al., 2006), there is general agreement that deep ocean is a large carbon

\footnotetext{
* Corresponding author. First Institute of Oceanography, SOA, Qingdao, 266061, China.

** Corresponding author. First Institute of Oceanography, SOA, Qingdao, 266061 China.

E-mail addresses: xfshi@fio.org.cn (X. Shi), chenzia@fio.org.cn (Z. Chen).
}

reservoir accounting for the major amplitude of $\mathrm{CO}_{2}$ glacialinterglacial variability in the past (Adkins et al., 2002; Sigman and Boyle, 2000; 2007; Watson and NaveiraGarabato, 2006; Toggweiler et al., 2006; Sikes, 2012).

It is proposed that changes in Southern Ocean upwelling is of crucial importance on regulating atmospheric $\mathrm{CO}_{2}$ levels during Terminations. That is, the enhanced upwelling, perhaps associated with changes in Southern Westerlies, will stimulate the ventilation of carbon-rich deep water mass to the surface, promoting the $\mathrm{CO}_{2}$ outgassing and finally triggering the global warming and Terminations (Skinner et al., 2010; Anderson et al., 2009). This hypothesis is supported by various paleoceanographic records broadly (e.g. ${ }^{13} \mathrm{C}$-depleted carbon during deglaciation (Köhler et al., 2005; Smith et al., 1999; Spero and Lea, 2002), Nd isotope records in the Tobago Basin and East Equatorial Pacific (Pahnke et al., 2008; Pena et al., 2013), acute drop in deglacial ${ }^{14} \mathrm{C}$ activity of dissolved inorganic carbon (DIC) in North Pacific intermediate waters (Marchitto et al., 
2007), etc), indicating a vital role played by upwelling branches of the global meridional overturning circulation (MOC) during the last deglaciation (Anderson et al., 2009; Siani et al., 2013).

From physical oceanographic perspective, upwelling regions in the SO consists of two branches associated with the upper and lower cell of global MOC, respectively in north and south of Antarctic Divergence Zone (Lumpkin and Speer, 2007; Marshall and Speer, 2012; Fig. 1B). The $27.6 \mathrm{~kg} \mathrm{~m}^{-3}$ density surface, outcropping south of the polar front all the way around Antarctica (see the red line in Fig. 1B), represents the average boundary between the upper and lower MOC cells in the SO (Marshall and Speer, 2012). Plenty of studies already demonstrated the variability of the upwelling strength associated with the upper cell during the last deglaciation (e.g. Anderson et al., 2009; Skinner, 2012), however, no reports exist discussing the upwelling in the lower cell. The latter is thus highly desirable to fully understand the outgassing process associated with the SO upwelling variability.

Consumption of dissolved silicic acid $\left(\mathrm{H}_{4} \mathrm{SiO}_{4}\right)$ by primary producers (diatoms) and cycling pathways represents primary prerequisites for effective carbon sequestration (Ragueneau et al., 2000). Diatoms live in the euphotic zone where they utilize the silicic acid to form opal tests. Although iron could limit the physiological status and growth rate of individual diatom cells (Boyd et al., 2000), biogenic opal productivity is ultimately limited by the supply of dissolved Si acid (Pondaven et al., 2000; Nelson et al., 2002). The paucity of silicate in the modern high-latitude Southern Ocean surface waters (Fig. 1B) has inspired the use of biogenic opal export as a measure of the silicate-rich deep waters upwelling to surface (Gnanadesikan and Toggweiler, 1999; Anderson et al., 2009; Meckler et al., 2013).

\section{Materials and methods}

The gravity core P1-03 was drilled from the front edge of the continental slope deposition fan off the Prydz Bay $\left(73^{\circ} 00^{\prime} 56^{\prime \prime} \mathrm{E}\right.$, $65^{\circ} 59^{\prime} 22^{\prime \prime} \mathrm{S}$ ) with a water depth of $2,542 \mathrm{~m}$ during the "30th Chinese National Antarctic Research Expedition" cruise in 2013-2014, (Fig. 1). P1-03 lies in the south of the $27.6 \mathrm{~kg} \mathrm{~m}^{-3}$ density surface outcropping location, having the potential to trace the surface Silicic Acid situation in the lower cell of the global MOC. The core is $5.64 \mathrm{~m}$ long, and the sediments mostly consist of gray clay silt without turbidite. The core was subsampled at an interval of $2 \mathrm{~cm}$ and totally 282 samples were prepared for the next analysis.
The $\mathrm{AMS}^{14} \mathrm{C}$ datum was determined from 4 sediment layers for organic carbon and carbonate carbon at Beta Analytic Lab, Miami, USA (Table 1). Organic matter is measured on acid insoluable organic carbon component of bulk samples and carbonate carbon is manually picked up from planktonic foraminifera Neogloboquadrina pachyderma $(\sin )(150-250 \mu \mathrm{m})$. We converted the $\mathrm{AMS}^{14} \mathrm{C}$ age into the calibrated calendar age using the online program Calib 7.04 (Stuiver and Reimer, 1993) and $\triangle R$ value 830a according to Domack et al. (2001) in Palmer Deep west of Antarctic Peninsula.

The measurements of X-ray fluorescence (XRF) scanning for P103 were performed with an Avaatech XRF Core Scanner at Tongji University. Data were obtained at a resolution of $1 \mathrm{~cm}$ over an area of $1.2 \mathrm{~cm}^{2}$ directly at the split core surface of the archive half, and we got the relative contents of the 29 elements from Al to Ba. The core surface was covered with $4 \mathrm{~mm}$ thick SPEXCerti Prep Ultralene 1 foil to avoid contamination of the XRF measurement unit. Although the XRF data is unable to provide the percentage of elements, it has a positive correlation with the ICP-MS measured element contents (Tjallingii et al., 2007), and they have a linear logarithmic relationship (Weltje and Tjallingii, 2008). The calculations of normative $\mathrm{Ba} / \mathrm{Ti}, \mathrm{Si} / \mathrm{Al}, \mathrm{Ca} / \mathrm{Ti}$ are based on the assumption that sedimentary $\mathrm{Ti}$ and $\mathrm{Al}$ are of detrial origin, and the composition of the $\mathrm{Ti}$ and $\mathrm{Al}$ bearing phases of the terrigenous material (detrial $\mathrm{Ba} / \mathrm{Ti}, \mathrm{Si} / \mathrm{Al}, \mathrm{Ca} / \mathrm{Ti}$ ) remained constant in space and time (Jaccard et al., 2009). In order to evaluate biogenic Ba, Si and Ca components, eliminate the influence of terrigenous material and deposition "dilution effect", the normative calculations to $\mathrm{Al}$ and $\mathrm{Ti}$ have been widely applied in recent studies (Murray and Leinen, 1996; 2000; Wei et al., 2003).

Biogenic opal was determined by alkaline extraction of silica (Mortlock and Froelich, 1989), and average errors for this method range from 0.2 to $1.0 \%$. Biogenic opal percentage was measured by molybdate-blue spectrophotometry at key laboratory of Marine Sedimentology and Environmental Geology.

Both sieve analysis and a laser particle sizer (Malvern Mastersizer 2000) were used for grain size measurement. First, $\mathrm{H}_{2} \mathrm{O}_{2}$ was used to remove organic material, and $\mathrm{HCl}\left(0.25 \mathrm{~mol} \mathrm{l}^{-1}\right)$ to remove $\mathrm{CaCO}_{3}$. Samples were then placed in a water bath at $85{ }^{\circ} \mathrm{C}$ for $4 \mathrm{~h}$ and $\mathrm{Na}_{2} \mathrm{CO}_{3}\left(1 \mathrm{~mol} \mathrm{l}^{-1}\right)$ was added to remove biogenic silica (opal). Samples were washed using de-ionized water and dried. The coarser fraction was retained on a mesh ( $>2 \mathrm{~mm}$, gravel), weighed and its abundance calculated in percent weight. The finer fractions
A

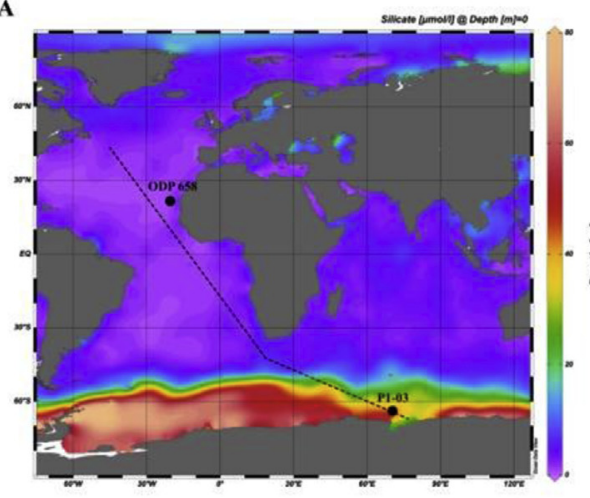

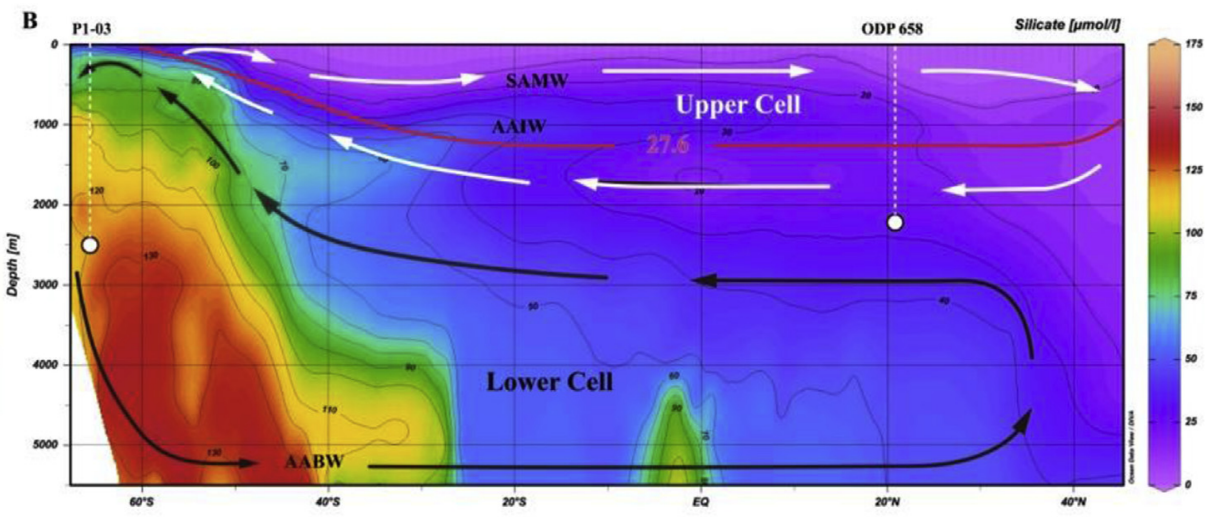

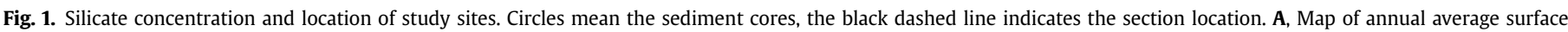

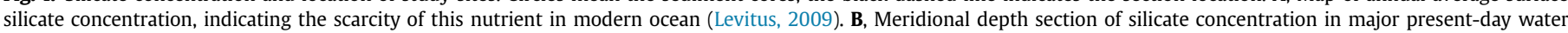

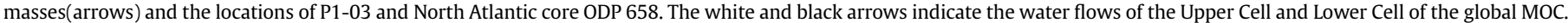

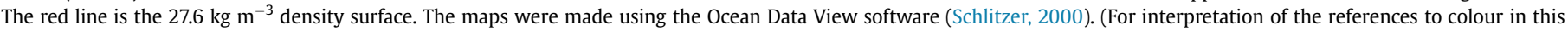
figure legend, the reader is referred to the web version of this article.) 


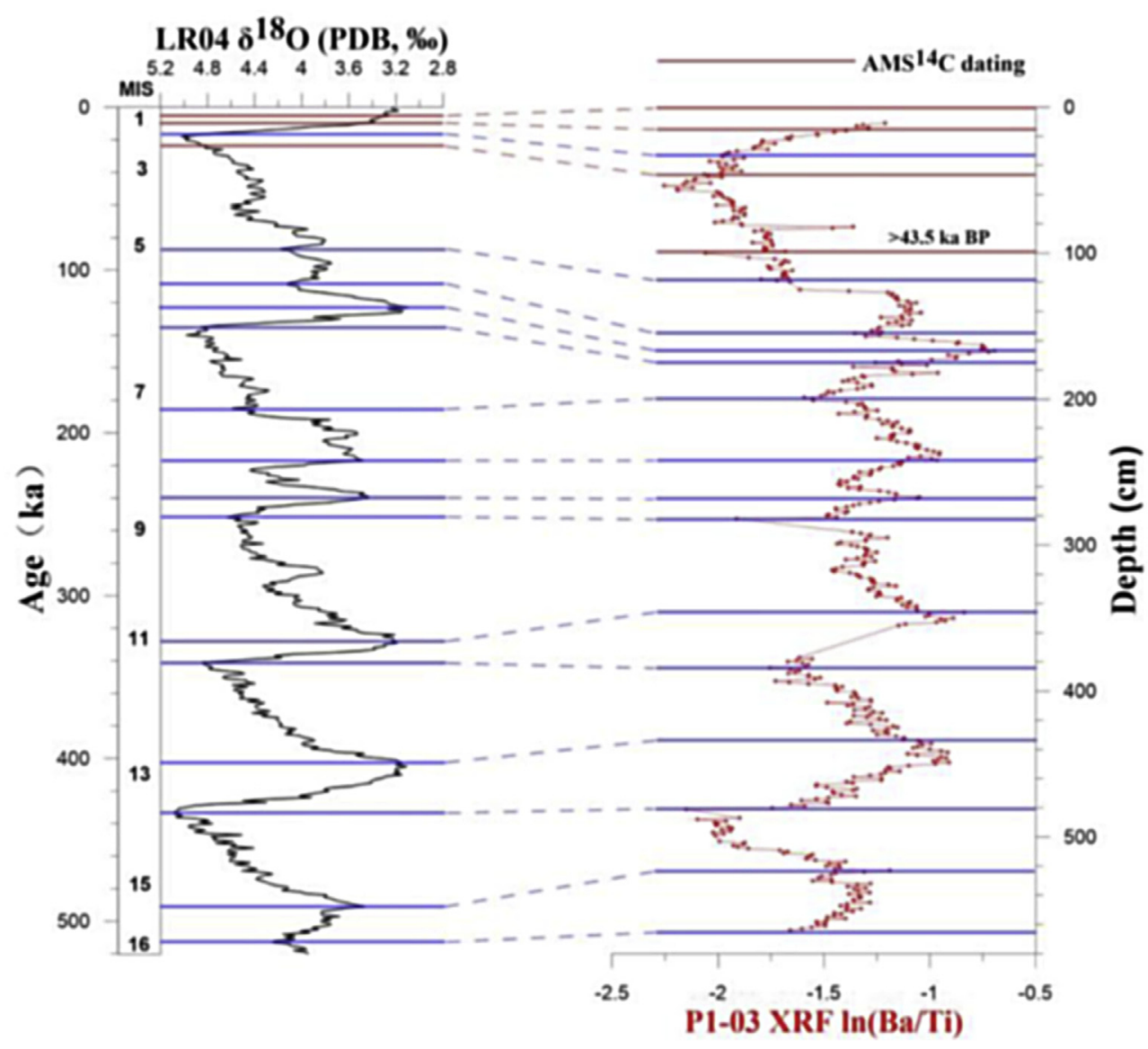

Fig. 2. Comparison between the XRF $\ln \left(\mathrm{Ba} / \mathrm{Ti}\right.$ ) curve of Core P1-03 and the stacked global benthic LR04 $\delta^{18} \mathrm{O}$ (Lisiecki and Raymo, 2005). The solid red lines indicate Accelerator Mass Spectrometry (AMS) $)^{14} \mathrm{C}$ dating layers, and the solid blue lines indicate chronologic tie points. (For interpretation of the references to colour in this figure legend, the reader is referred to the web version of this article.)

Table 1

AMS ${ }^{14} \mathrm{C}$ age and calibrated age of core P1-03.

\begin{tabular}{|c|c|c|c|}
\hline Depth $(\mathrm{cm})$ & $\mathrm{AMS}^{14} \mathrm{C}$ age (a.BP) & Calibrated age (a.BP( $1 \sigma))$ & Dating material \\
\hline $0-2$ & $5560 \pm 30$ & $4961 \pm 59$ & Organic Carbon \\
\hline $16-18$ & $11,890 \pm 40$ & $12,607 \pm 40$ & Organic Carbon \\
\hline $44-46$ & $18,360 \pm 60$ & $22,265 \pm 106$ & Organic Carbon \\
\hline $98-100$ & $>43,500$ & & planktonic foraminifera (N. pachyderma) \\
\hline
\end{tabular}

$(<2 \mathrm{~mm})$ were immersed in de-ionized water, scattered by sodium metaphosphate and analysed with a laser particle sizer.

\section{Results}

\subsection{Chronological framework}

Our sediment core spans the last four glacial-interglacial cycles starting from MIS13 (Figs. 3 and 4). Due to the absence of biogenic carbonate associated with development of continuous foraminiferal oxygen isotope stratigraphy and carbonate-based $\mathrm{AMS}^{14} \mathrm{C}$ data series in the studied core P1-03, we established the age model by organic carbon $\mathrm{AMS}^{14} \mathrm{C}$ dates for the last $30 \mathrm{ka} \mathrm{BP}$ and by the correlation of $\mathrm{Ba} / \mathrm{Ti}$ with $\mathrm{LR04}$ stacked stable oxygen isotope for the older record (Lisiecki and Raymo, 2005). In a recent study (Wu et al., 2015), based on the close coupling between bioBa and LR04 curve, biogenic Ba has been chosen to reconstruct the age model of sediment core at Prydz trough during the late quaternary. BioBa is a primary productivity proxy in paleoceanography study (Bonn et al., 1998; Dymond, 1992; Paytan and Griffith, 2007; Schenau et al., 2001; Tribovillard et al., 2006). Given the interglacial high productivity and glacial low productivity in the south of the Polar Front (Jaccard et al., 2013; Lamy et al., 2014; Anderson et al., 2014), the variation of primary productivity thus is in close relationship with climate changes during glacial interglacial cycles. Assuming that sedimentary $\mathrm{Ti}$ is of detrial origin, Ba abundance normalized to $\mathrm{Ti}$ yields an estimate of the sedimentary concentration of biogenic Ba (Bonn et al., 1998; Nurberg et al., 1997; Schroeder et al., 1997), which serves as a tool to reconstruct the chronological framework. Eighteen stratigraphic tie points for the study core P1-03 (including the organic carbon $\mathrm{AMS}^{14} \mathrm{C}$ dates, Table 1) was chosen for detailed comparison with the standard LR0 $4 \delta^{18} \mathrm{O}$ stack (Fig. 2). During MIS 2 and MIS 1 with $3 \mathrm{AMS}^{14} \mathrm{C}$ dates, the closely correlation between $\mathrm{Ba} /$ Ti and LR04 (Fig. 2) could verify the reasonableness of the age 


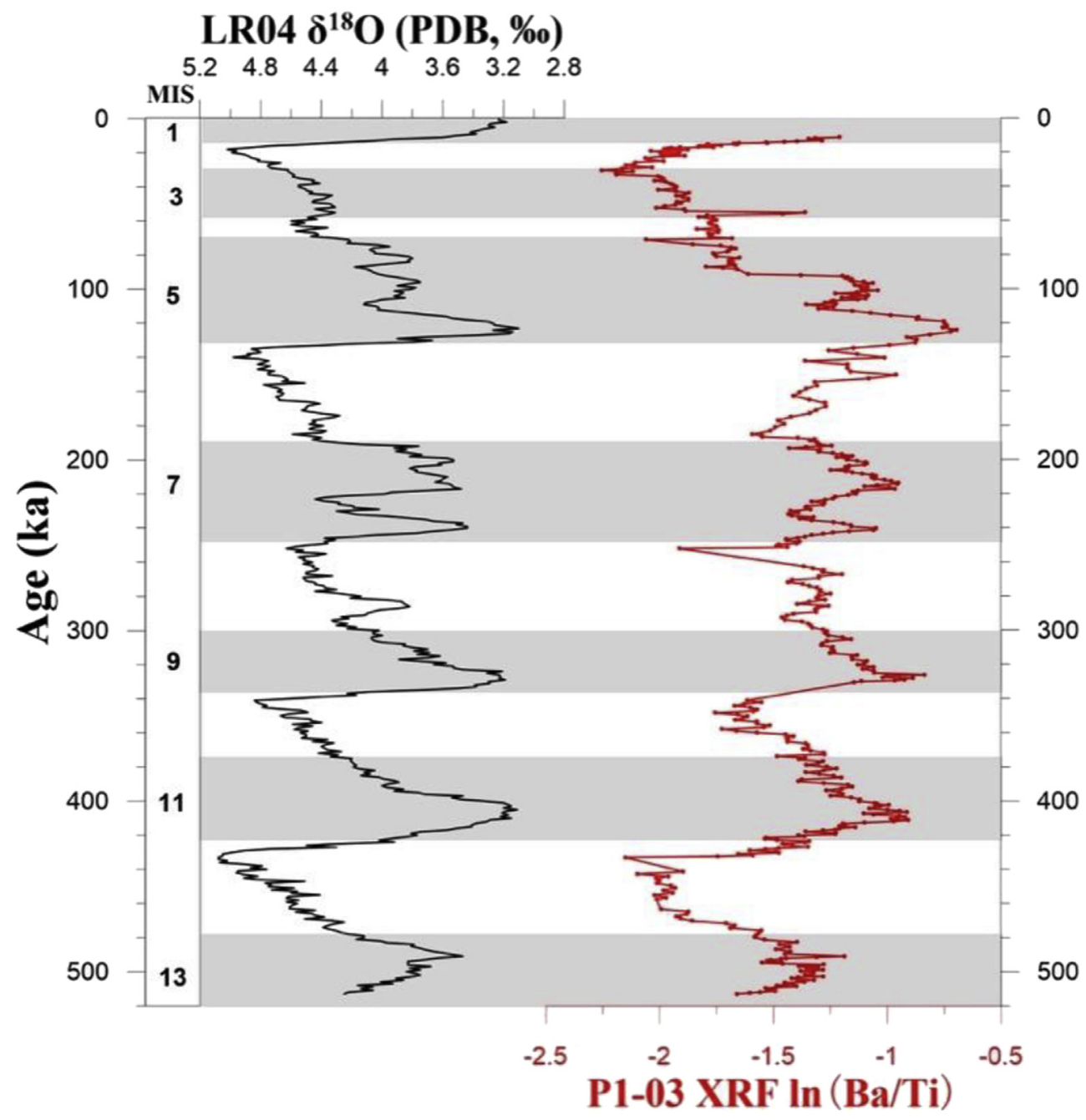

Fig. 3. Chronological framework and comparison between the XRF ln(Ba/Ti) curve of Core P1-03 and the stacked global benthic LR04 $\delta^{18} \mathrm{O}$ (Lisiecki and Raymo, 2005).

framework reconstruction. By graphical comparing the P1-03 XRF $\mathrm{Ba} / \mathrm{Ti}$ curve with the LR04 $\delta^{18} \mathrm{O}$ stack, Core P1-03 spans the last 513 ka covering the Marine Isotope Stage (MIS) 1-13 (Fig. 3).

\subsection{Biogenic opal content and $X R F \ln (S i / A l)$}

Both the biogenic opal contents (\%) and the XRF $\ln (\mathrm{Si} / \mathrm{Al}$ ) (Fig. 4) are characterized by pronounced peaks during each glacial termination. They are very similar to the deglacial opal peaks in the record from the subtropical North Atlantic, at Ocean Drilling Program (ODP) Site $658\left(20^{\circ} 44^{\prime} 57^{\prime \prime} \mathrm{N}, 18^{\circ} 34^{\prime} 51^{\prime \prime} \mathrm{W}, 2263 \mathrm{~m}\right.$ water depth) (Tiedemann et al., 1989; Meckler et al., 2013). The biogenic opal contents are characterized by a relatively wide range of parameter values (3.67-21.66), with average values of 9.17, similar with the core ODP-658 average values of 10.61. Besides the deglacial opal peaks, the biogenic opal and $\ln (\mathrm{Si} / \mathrm{Al})$ generally display clear glacial/ interglacial oscillation with higher values during interglacials.

\section{3. $X R F \ln (\mathrm{Ca} / \mathrm{Ti})$}

The $\mathrm{XRF} \ln (\mathrm{Ca} / \mathrm{Ti})$ is used as a proxy for carbonate preservation, and the values span from 0.24 to 1.82 with an average 0.57 (Fig. 4J). The low values of $\ln (\mathrm{Ca} / \mathrm{Ti})$ during glacial terminations are supposed to correspond to the dramatic increasing of Epica Dome $\mathrm{C}$
$\mathrm{CO}_{2}$ concentration in Fig. 4 (Siegenthaler et al., 2005).

\subsection{Sand fraction of sediment}

We use the sand fraction data to evaluate the terrestrial influence during glacial terminations (Fig. 4M). This data is characterized by a wide range of values (0-61.74\%), with average values of $12.08 \%$. There is no significant correlation between sand fraction and biogenic opal contents, implying the terrestrial influence on biogenic opal could be ignored. Especially the relative low values in glacial terminations, indicating that the deglacial opal peaks are not terrestrial sourced.

\section{Discussion}

\subsection{Deglacial opal peaks and enhanced Southern Ocean upwelling}

The biogenic opal concentration of core P1-03 is characterized by pronounced peaks during each glacial termination (Fig. 4I), indicating a maxima in opal production. Meanwhile, it is noted that the $\ln (\mathrm{Si} / \mathrm{Al})$ record varies in line with the deglacial opal peaks (Fig. $4 \mathrm{H})$. On one hand, opal preservation efficiency in the SO is not significantly different from the global average (2-6\%; DeMaster, 2002; Nelson et al., 2002; Pondaven et al., 2000); on the other 


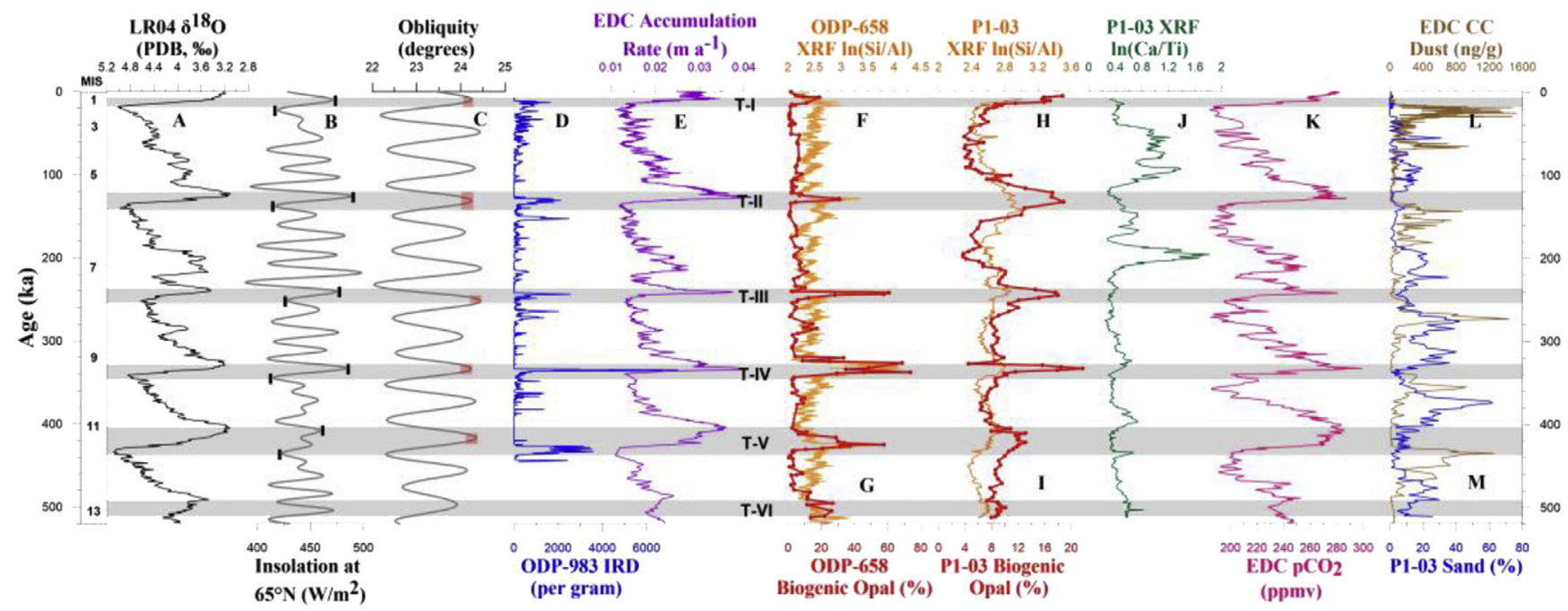

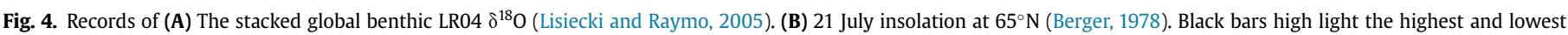

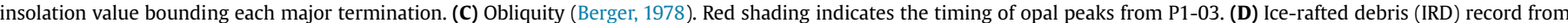

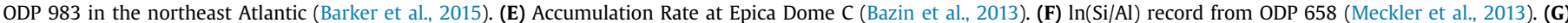

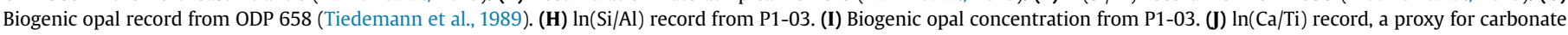

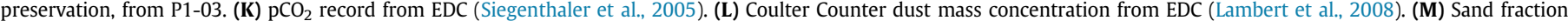

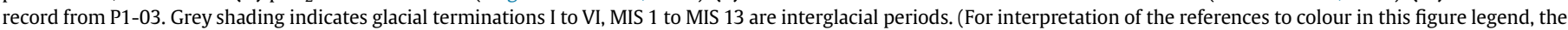
reader is referred to the web version of this article.)

hand, the glacial-interglacial variation of biogenical opal coincides with primary productivity as inferred from $X R F \ln (\mathrm{Ba} / \mathrm{Ti}$ ) (Fig. 3). All together, this confirms that the sedimentary opal variation represents production changes rather than preservation efficiency. In addition, it is worthy noting that there is no significant correlation between Sand/EDC CC Dust and our biogenic opal record (Lambert et al., 2008), especially during glacial terminations (Fig. 4 L and M). This indicates that the influence of terrigenous and airborne dust on the opal record is trivial.

We attribute the deglacial opal peaks to the enhanced supply of dissolved Si to thermocline and surface water in upwelling regions of the MOC lower cell, where upwelled silicate rich deep-water masses were at its maximum during deglaciation. The enhanced ventilation associated with increased upwelling in the SO, would lead to an increase in both $\mathrm{Si}$ and oceanic Fe supply to surface waters and promote opal production (Ayers and Strutton, 2013). Our results, consistent with other opal flux records in Southern Ocean (Chase et al., 2003; Anderson et al., 2009), indicate the key role of the upwelling branch on nutrient supply to the surface as emphasized in the latest MOC diagram (Marshall and Speer, 2012).

\subsection{Impact on low-latitude surface and thermocline waters}

Enhanced upwelling in the SO during deglaciation would have introduced the Si-rich signature during the formation of Antarctic Intermediate Water (AAIW) and Subantarctic Mode Water (SAMW), which are known to feed the lower thermocline in the low latitude (Sarmiento et al., 2004). If the deglacial opal peaks in the lower cell were truly a chemical signature of enhanced MOC upwelling branch of the SO (Fig. $4 \mathrm{H}$ and I), an attendant maximum supply of dissolved $\mathrm{Si}$ and the growth of diatoms in low-latitude regions would be expected. We use the opal production at a site in subtropical North Atlantic to test this prediction (Fig. 1). A clear deglacial correlation between the high-latitude SO and lowlatitude are found in the similar time range (Fig. 4; Meckler et al., 2013).

Coincidentally, enhanced supply of southern sourced Si-rich water drove the major ecological changes observed in the other low-latitude area during glacial terminations (Kienast et al., 2006; Bradtmiller et al., 2006, 2009; Anderson et al., 2009; Pahnke et al., 2008; Calvo et al., 2011; Hendry and Robinson, 2012), indicating a pervasive opal peaks during deglaciation. Other evidence also indicates the increased Southern Ocean upwelling and deepwater injection into low-latitude thermocline during glacial terminations, such as $\triangle^{14} \mathrm{C}$ record from Southeast Pacific (Siani et al., 2013), Nd isotope record from the Tobago Basin and East Equatorial Pacific (Pahnke et al., 2008; Pena et al., 2013), widespread minimum in $\delta^{13} \mathrm{C}$ of planktonic foraminifera (Spero and Lea, 2002), $\delta^{13} \mathrm{C}$ record of atmospheric $\mathrm{CO}_{2}$ derived from the Taylor Dome ice core (Smith et al., 1999).

However, it has also been speculated that the Si-rich water feeding the low-latitude opal peaks originated from the upward mixing of abyssal water (Meckler et al., 2013). But the similarity of the deglacial opal peaks in the low-latitude Atlantic and Pacific Oceans would require a process that could operate in both basins despite the different deep-water mass configurations (Bradtmiller et al., 2006, 2007). Moreover, the deglacial $\mathrm{CO}_{2}$ outgassing that spread via AAIW pathway (partly) (Siani et al., 2013), could be used to argue against the alternative deep mixing mechanism. So we suggest that increase in the silicate concentration or formation rate of SAMW or AAIW could play a more important role than this coexist mechanism.

\subsection{Link to Northern Hemisphere summer insolation and atmospheric $\mathrm{CO}_{2}$}

Since Termination $V$, each glacial termination occurs when boreal summer insolation intensity begins to rise at a low value, with much of the remainder occurring during the rising limb of the insolation curve (Fig. 4B). This means not only the termination is strongly correlated with the rising boreal summer insolation, but also rising insolation plays a key role in driving the termination to completion. This hypothesis is supported by empirical evidence from the stalagmite (Cheng et al., 2009) as well as climate modeling (He et al., 2013). The amount and rate of insolation rising may also be important controls on ice sheets (Cheng et al., 2009), then 
influence the Southern Ocean upwelling. Supporting this idea is the observation that the two terminations with low opal peaks (T-III and $\mathrm{T}-\mathrm{V}$ ) are associated with relatively low insolation shifts. In contrast, the terminations with high opal peaks (T-I, T-II and T-IV) are associated with high magnitudes. The Termination VI, with the insolation shift and decline during this period, has the least significant opal peak value (Fig. 4 B,I). Because of the resolution of our age model and the graphical comparing with the orbital tuned LR04 $\delta^{18} \mathrm{O}$ stack, it's a pity that we don't have a chance to get the precise evaluation on "which is the driving force", especially for the completely orbital forcing driven insolation. However, we could suggest that there is a close relationship between the boreal summer insolation and SO upwelling, by the good correlation between these parameters.

Increased upwelling in the Southern Ocean, inferred from the opal records, coincided with the deglacial rise in atmospheric $\mathrm{CO}_{2}$ (Fig. 4K). During deglaciation, the weakest carbonate preservation in the deep Southern Ocean derived from XRF $\ln (\mathrm{Ca} / \mathrm{Ti})$, was consistent with $\mathrm{CO}_{2}$ increasing, and the maximum in the rate of $\mathrm{CO}_{2}$ rise was synchronous with the opal peaks (Fig. 4I). These lead us to conclude that enhanced upwelling of the Southern Ocean was a primary contributor to the deglacial rise in atmospheric $\mathrm{CO}_{2}$. Our results also support the interpretation with respect to the SO ${ }^{14} \mathrm{C}$ depleted deep water during LGM and its injection into intermediate waters during deglaciation, in line with rising atmospheric $\mathrm{CO}_{2}$ (Marchitto et al., 2007; Sikes, 2012).

\subsection{Termination mechanisms}

Along with the growing realization of the key role played by the upwelling branch of the MOC on climate system, the Southern Ocean becomes a focus to understand processes associated with modern and ancient climate variability (Huybers and Wunsch, 2010; Marshall and Speer, 2012). A series of mechanisms have been proposed to explain the central role played by the upwelling branch of the Southern Ocean on regulating the glacial-interglacial variation of atmospheric $\mathrm{CO}_{2}$ changes. First, Northern Hemisphere cooling during glacials could cause a reorganization of global atmospheric circulation, leading to a southward movement in the Southern Hemisphere westerlies (Law et al., 2008; Toggweiler and Russell, 2008; Govin et al., 2009; Anderson et al., 2009; Abarzúa, 2012; Lamy, 2012). This facilitates the upwelling branch of the MOC and enhances the ventilation between the abyss and the surface, promoting atmospheric $\mathrm{CO}_{2}$ increase, and resulting in observed productivity peaks (Anderson et al., 2009). This mechanism is further supported by the coincident southward shift/ intensification of the Southern Hemisphere westerlies inferred from EDC accumulation rate record (Bazin et al., 2013; WAIS, 2013; Fig. 4E) during terminations. Second, the bipolar seesaw mechanism (Stocker and Johnsen, 2003). A cessation of the MOC in the Northern Hemisphere induced by freshwater injection owing to the North Atlantic/Arctic ice sheet retreat (Zhang et al., 2013), supported by IRD record in the North Atlantic (Barker et al., 2015; Fig. 4D), could warm the southern hemisphere. As a consequence, this will cause sea-ice retreat in the Southern Ocean, promoting $\mathrm{CO}_{2}$ outgassing (Keeling and Stephens, 2001). Third, sea-ice cover (Stephens and Keeling, 2000). Retreated sea ice cover in deglacial times could have allowed winds to drive air-sea exchange more efficiently between deep and surface waters, thereby increased the concentration of atmospheric $\mathrm{CO}_{2}$ (Cheng et al., 2009; Marshall and Speer, 2012). This effect would be amplified by sea-ice/albedo feedback. Fourth, Antarctic local orbital forcing might act together with the Northern Hemispere during the terminations, by caused the sea-ice decline and the increased interhemispheric temperature gradient (Laepple et al., 2011; WAIS, 2013).
Our results show that opal peaks occur in line with Northern Hemisphere summer insolation and IRD peaks during terminations. We agree with the scenario in which a set of mechanisms is ultimately linked to the rise in boreal summer insolation that eventually causes $\mathrm{CO}_{2}$ rise. The rising insolation may trigger the initial disintegration of the massive ice sheet, which in turn stimulates a weakening of MOC as well as a cold anomaly in the Northern Hemisphere. The resulting warming in the Southern Ocean, associated with bipolar thermal seesaw, causes the sea ice retreat and changes in Southern Westerlies, promoting $\mathrm{CO}_{2}$ outgassing and glacial terminations (Broecker et al., 1985, Broecker, 1998; Crowley, 1992; Stocker et al., 1992, Stocker and Johnsen, 2003; Blunier and Brook, 2001; Wang et al., 2007; Toggweiler and Russell, 2008; Anderson et al., 2009).

\section{Conclusions}

In this study we report a record covering the last $\sim 500 \mathrm{ka}$ from Prydz Bay in south of Antarctic Divergence Zone (i.e. upwelling regions of the lower cell of the global MOC). Within the age uncertainty, the opal peaks in our records are identified to be accompanied with $\mathrm{CO}_{2}$ rise during the last 6 terminations. Our results thus provide additional evidence to support the role played by the Southern Ocean upwelling on $\mathrm{CO}_{2}$ outgassing.

The chronology of our records cannot provide precise phase comparison with the core from subtropical North Atlantic, and thus can not support/role out the role of enhanced vertical diffusion in the tropics on $\mathrm{CO}_{2}$ outgassing. High resolution records with more reliable age model are thus still required to evaluate their roles on $\mathrm{CO}_{2}$ outgassing in the future. Due to the limitation of paleomagnetic analysis in the high latitude, we give up building age model via comparison of relative paleointensity (RPI) between P1-03 and global reference stack in this study. Fortunately, the relative abundance of diatom Eucampia antarctica - - a sea surface temperature proxy, has the potential to build a reliable chronological framework by comparison to the Antarctic ice core local temperature reconstruction (Jaccard et al., 2016). We are planning to apply this approach in subsequent research, and compare the new age framework to this study.

\section{Acknowledgements}

This work was jointly supported by the Chinese Polar Environment Comprehensive Investigation \& Assessment Programs (Grant no. CHINARE2015-01-02), Basic Scientific Fund for National Public Research Institutes of China (Grant no. 2014G06), the National Natural Science Foundation of China (Grant no. 41406220, U1606401), National Programme on Global Change and Air-Sea Interaction (Grant no. GASI-GEOGE-06-02), Postdoctoral Foundation of Qingdao, Postdoctoral Innovation Foundation of Shandong Province, and Taishan Scholar Program of Shandong Province. We are grateful to the crew of the R/V Xuelong for their assistance with sample collection in the 30th Chinese National Antarctic Research Expeditions, and thanks to the Chinese Repository of Polar Sediments for providing samples. We acknowledge Li Wu, JianJun Zou and ZhiFang Xiong for paper modification. We also thank State Key Laboratory of Marine Geology in Tongji University for the sediment core XRF measurement.

\section{References}

Abarzúa, A.M., 2012. 19,000 cal yrs of Southern Westerlies changes from lake sediments, Chile ( 38 to $44^{\circ} \mathrm{S}$ ). Ouat. Int. 279-280, 9.

Adkins, J.F., McIntyre, K., Schrag, D.P., 2002. The salinity, temperature, and $\delta 180$ of the glacial deep ocean. Science 298 (5599), 1769-1773.

Anderson, R., Ali, S., Bradtmiller, L., Nielsen, S., Fleisher, M., Anderson, B., Burckle, L. 
2009. Wind-driven upwelling in the Southern Ocean and the deglacial rise in atmospheric CO2. science 323 (5920), 1443-1448.

Anderson, R.F., Barker, S., Fleisher, M., Gersonde, R., Goldstein, S.L., Kuhn, G. Mortyn, P.G., Pahnke, K., Sachs, J.P., 2014. Biological response to millennial variability of dust and nutrient supply in the Subantarctic South Atlantic ocean philosophical transactions of the Royal society of London a: mathematical. Phys. Eng. Sci. 372 (2019), 20130054

Archer, D.E., Eshel, G., Winguth, A., Broecker, W., Pierrehumbert, R., Tobis, M. Jacob, R., 2000. Atmospheric pCO2 sensitivity to the biological pump in the ocean. Global Biogeochem. Cycles 14 (4), 1219-1230.

Ayers, J.M., Strutton, P.G., 2013. Nutrient variability in subantarctic mode waters forced by the southern annular mode and ENSO. Geophys. Res. Lett. 40 (13) 3419-3423.

Barker, S., Chen, J., Gong, X., Jonkers, L., Knorr, G., Thornalley, D., 2015. Icebergs not the trigger for North Atlantic cold events. Nature 520 (7547), 333-336.

Bazin, L., et al., 2013. The Antarctic Ice Core Chronology (AICC2012). http:/ dx.doi.org/10.1594/PANGAEA.824894.

Berger, A., 1978. Long-term variations of caloric insolation resulting from the Earth's orbital elements. Quat. Res. 9 (2), 139-167.

Blunier, T., Brook, E.J., 2001. Timing of millennial-scale climate change in Antarctica and Greenland during the last glacial period. Science 291 (5501), 109-112.

Bonn, W.J., Gingele, F.X., Grobe, H., Mackensen, A., Fütterer, D.K., 1998. Palaeoproductivity at the Antarctic continental margin: opal and barium records fo the last 400 ka. Palaeogeogr. Palaeoclimatol. Palaeoecol. 139 (3), 195-211.

Boyd, P.W., Watson, A.J., Law, C.S., Abraham, E.R., Trull, T., Murdoch, R. Bakker, D.C.E., Bowie, A.R., Buesseler, K.O., Chang, H., 2000. A mesoscale phytoplankton bloom in the polar Southern Ocean stimulated by iron fertilization. Nature 407 (6805), 695-702.

Bradtmiller, L.I., Anderson, R.F., Fleisher, M.Q., Burckle, L.H., 2009. Comparing glacial and holocene opal fluxes in the Pacific sector of the Southern Ocean. Paleoceanography 24 (2).

Bradtmiller, L.I., Anderson, R.F., Fleisher, M.Q., Burckle, L.H., 2007. Opal burial in the equatorial Atlantic Ocean over the last 30 ka: implications for glacialinterglacial changes in the ocean silicon cycle. Paleoceanography 22 (4).

Bradtmiller, L.I., Anderson, R.F., Fleisher, M.Q., Burckle, L.H., 2006. Diatom productivity in the equatorial Pacific Ocean from the last glacial period to the present: a test of the silicic acid leakage hypothesis. Paleoceanography 21 (4).

Broecker, W.S., 1998. Paleocean circulation during the last deglaciation: a bipolar seesaw? Paleoceanography 13 (2), 119-121.

Broecker, W.S., Peteet, D.M., Rind, D., 1985. Does the ocean-atmosphere system have more than one stable mode of operation? Nature 315 (6014), 21-26.

Calvo, E., Pelejero, C., Pena, L.D., Cacho, I., Logan, G.A., 2011. Eastern Equatorial Pacific productivity and related-CO2 changes since the last glacial period. Proc. Natl. Acad. Sci. 108 (14), 5537-5541.

Chase, Z., Anderson, R.F., Fleisher, M.Q., Kubik, P.W., 2003. Accumulation of biogenic and lithogenic material in the Pacific sector of the Southern Ocean during the past 40,000 years. Deep Sea Res. Part II Top. Stud. Oceanogr. 50 (3), 799-832.

Cheng, H., Edwards, R.L., Broecker, W.S., Denton, G.H., Kong, X., Wang, Y., Zhang, R Wang, X., 2009. Ice age terminations. Science 326 (5950), 248-252.

Crowley, T.J., 1992. North Atlantic deep water cools the southern hemisphere Paleoceanography 7 (4), 489-497.

DeMaster, D.J., 2002. The accumulation and cycling of biogenic silica in the Southern Ocean: revisiting the marine silica budget. Deep Sea Res. Part II: Topic Stud. Oceanogr. 49 (16), 3155-3167.

Domack, E., Leventer, A., Dunbar, R., Taylor, F., Brachfeld, S., Sjunneskog, C., 2001. Chronology of the palmer deep site, Antarctic Peninsula: a holocene palaeoenvironmental reference for the circum-Antarctic. Holocene 11 (1), 1-9.

Dymond, J., 1992. Barium in deep-sea sediment: a geochenucal proxy for paleoproductivity. Paleoceanography 7 (2), 163-181.

Gnanadesikan, A., Toggweiler, J.R., 1999. Constraints placed by silicon cycling on vertical exchange in general circulation models. Geophys. Res. Lett. 26 (13) 1865-1868.

Govin, A., Michel, E., Labeyrie, L., Waelbroeck, C., Dewilde, F., Jansen, E., 2009. Evidence for northward expansion of Antarctic bottom water mass in the Southern Ocean during the last glacial inception. Paleoceanography 24 (1).

He, F., Shakun, J.D., Clark, P.U., Carlson, A.E., Liu, Z., Otto-Bliesner, B.L., Kutzbach, J.E. 2013. Northern Hemisphere forcing of Southern Hemisphere climate during the last deglaciation. Nature 494 (7435), 81-85.

Hendry, K.R., Robinson, L.F., 2012. The relationship between silicon isotope fractionation in sponges and silicic acid concentration: modern and core-top studies of biogenic opal. Geochim. Cosmochim. Acta 81, 1-12.

Huybers, P., Wunsch, C., 2010. Paleophysical oceanography with an emphasis on transport rates Marine. Science 2.

Jaccard, S.L., Galbraith, E.D., Sigman, D.M., Haug, G.H., Francois, R., Pedersen, T.F. Dulski, P., Thierstein, H.R., 2009. Subarctic Pacific evidence for a glacial deepening of the oceanic respired carbon pool. Earth Planet. Sci. Lett. 277 (1) $156-165$

Jaccard, S.L., Hayes, C.T., Martínez-García, A., Hodell, D.A., Anderson, R.F., Sigman, D.M., Haug, G.H., 2013. Two modes of change in Southern Ocean productivity over the past million years. Science 339 (6126), 1419-1423.

Jaccard, S.L., Galbraith, E.D., Martínez-García, A., Anderson, R.F., 2016. Covariation of deep Southern Ocean oxygenation and atmospheric CO2 through the last ice age. Nature 530 (7589), 207-210.

Keeling, R.F., Stephens, B.B., 2001. Antarctic sea ice and the control of Pleistocene climate instability. Paleoceanography 16 (1), 112-131.
Kienast, S.S., Kienast, M., Jaccard, S., Calvert, S.E., François, R., 2006. Testing the silica leakage hypothesis with sedimentary opal records from the eastern equatorial Pacific over the last 150 kyrs. Geophys. Res. Lett. 33 (15).

Köhler, P., Fischer, H., Munhoven, G., Zeebe, R.E., 2005. Quantitative interpretation of atmospheric carbon records over the last glacial termination. Glob. Biogeochem. Cycles 19 (4).

Laepple, T., Werner, M., Lohmann, G., 2011. Synchronicity of Antarctic temperatures and local solar insolation on orbital timescales. Nature 471 (7336), 91-94.

Lambert, F., Delmonte, B., Petit, J.R., Bigler, M., Kaufmann, P.R., Hutterli, M.A. Stocker, T.F., Ruth, U., Steffensen, J.P., Maggi, V., 2008. Dust-climate couplings over the past 800,000 years from the EPICA Dome C ice core. Nature 452, 616-619. Nature Publishing Group.

Lamy, F., 2012. Millennial-scale surface water changes in the Southeast Pacific over the past $\sim 70$ kyr. Quat. Int. 279-280, 264.

Lamy, F., Gersonde, R., Winckler, G., Esper, O., Jaeschke, A., Kuhn, G., Ullermann, J., Martínez-Garcia, A., Lambert, F., Kilian, R., 2014. Increased dust deposition in the Pacific Southern Ocean during glacial periods. Science 343 (6169), 403-407.

Law, R.M., Matear, R.J., Francey, R.J., 2008. Comment on saturation of the Southern Ocean CO2 sink due to recent climate change. science 319 (5863), 570-570.

Levitus, S., 2009. In NOAA Atlas NESDIS 68 184. US Govt Printing Office.

Lisiecki, L.E., Raymo, M.E., 2005. A Pliocene-Pleistocene stack of 57 globally distributed benthic $\delta 180$ records. Paleoceanography 20 (1). PA1003.

Lumpkin, R., Speer, K., 2007. Global ocean meridional overturning. J. Phys. Oceanogr. 37 (10), 2550-2562.

Marchitto, T.M., Lehman, S.J., Ortiz, J.D., Flückiger, J., van Geen, A., 2007. Marine radiocarbon evidence for the mechanism of deglacial atmospheric CO2 rise. science 316 (5830), 1456-1459.

Marshall, J., Speer, K., 2012. Closure of the meridional overturning circulation through Southern Ocean upwelling. Nat. Geosci.

Meckler, A., Sigman, D., Gibson, K., François, R., Martínez-García, A., Jaccard, S., Röhl, U., Peterson, L., Tiedemann, R., Haug, G., 2013. Deglacial pulses of deepocean silicate into the subtropical North Atlantic Ocean. Nature 495 (7442), 495-498.

WAIS Divide Project Members, 2013. Onset of deglacial warming in West Antarctica driven by local orbital forcing. Nature 500 (7463), 440-444.

Mortlock, R.A., Froelich, P.N., 1989. A simple method for the rapid determination of biogenic opal in pelagic marine sediments Deep Sea Research Part A. Oceanogr. Res. Pap. 36 (9), 1415-1426.

Murray, R., Leinen, M., 1996. Scavenged excess aluminum and its relationship to bulk titanium in biogenic sediment from the central equatorial Pacific Ocean. Geochim. Cosmochim. Acta 60 (20), 3869-3878.

Murray, R., Knowlton, C., Leinen, M., Mix, A., Polsky, C., 2000. Export production and terrigenous matter in the Central Equatorial Pacific Ocean during interglacial oxygen isotope Stage 11. Glob. Planet. Change 24 (1), 59-78.

Nelson, D.M., Anderson, R.F., Barber, R.T., Brzezinski, M.A., Buesseler, K.O., Chase, Z. Collier, R.W., Dickson, M.-L., François, R., Hiscock, M.R., 2002. Vertical budgets for organic carbon and biogenic silica in the pacific sector of the Southern Ocean, 1996-1998 deep sea research Part II. Top. Stud. Oceanogr. 49 (9), 1645-1674.

Nurberg, C., Bohrmann, G., Schuter, M., 1997. Barium accumulation in the Atlantic sector of the Southern Ocean: results from 190,000-years records. Paleoceanography 12 (4), 594-603.

Pahnke, K., Goldstein, S.L., Hemming, S.R., 2008. Abrupt changes in Antarctic Intermediate Water circulation over the past 25,000 years. Nat. Geosci. 1 (12), 870-874.

Pondaven, P., Ragueneau, O., Tréguer, P., Hauvespre, A., Dezileau, L., Reyss, J.L., 2000. Resolving the 'opal paradox'in the Southern Ocean. Nature 405 (6783), $168-172$.

Paytan, A., Griffith, E.M., 2007. Marine barite: recorder of variations in ocean export productivity Deep Sea Research Part II. Top. Stud. Oceanogr. 54 (5), 687-705.

Peacock, S., Lane, E., Restrepo, J.M., 2006. A possible sequence of events for the generalized glacial-interglacial cycle. Glob. Biogeochem. Cycles 20 (2).

Pena, L., Goldstein, S.L., Hemming, S.R., Jones, K.M., Calvo, E., Pelejero, C., Cacho, I., 2013. Rapid changes in meridional advection of Southern Ocean intermediate waters to the tropical Pacific during the last 30 kyr. Earth Planet. Sci. Lett. 368, $20 \mathrm{e} 32$.

Ragueneau, O., Tréguer, P., Leynaert, A., Anderson, R.F., Brzezinski, M.A., DeMaster, D.J., Dugdale, R.C., Dymond, J., Fischer, G., François, R., Heinze, C. Maier-Reimer, E., Martin-Jézéquel, V., Nelson, D.M., Quéguiner, B., 2000. A review of the Si cycle in the modern ocean: recent progress and missing gaps in the application of biogenic opal as a paleoproductivity proxy. Glob. Planet. Change 26 (4), 317-365.

Sarmiento, J.L., Gruber, N., Brzezinski, M.A., Dunne, J.P., 2004. High-latitude controls of thermocline nutrients and low latitude biological productivity. Nature 427 (6969), 56-60.

Schenau, S.J., Prins, M.A., De Lange, G.J., Monnin, C., 2001. Barium accumulation in the Arabian Sea: controls on barite preservation in marine sediments. Geochim. Cosmochim. Acta 65 (10), 1545-1556.

Schlitzer, R. 2000. Electronic atlas of WOCE hydrographic and tracer data now available EOS. Trans. Am. Geophys. Union 81 (5), 45-45.

Schroeder, J., Murray, R., Leinen, M., Pflaum, R., Janecek, T., 1997. Barium in equatorial Pacific carbonate sediment: terrigenous, oxide, and biogenic associations. Paleoceanography 12 (1), 125-146.

Siani, G., Michel, E., De Pol-Holz, R., DeVries, T., Lamy, F., Carel, M., Isguder, G., Dewilde, F., Lourantou, A., 2013. Carbon isotope records reveal precise timing of 
enhanced Southern Ocean upwelling during the last deglaciation. Nat. Commun. 4.

Siegenthaler, U., Stocker, T.F., Monnin, E., Lüthi, D., Schwander, J., Stauffer, B., Raynaud, D., Barnola, J.-M., Fischer, H., Masson-Delmotte, V., Jouzel, J., 2005. Stable carbon CycleClimate relationship during the late Pleistocene. Science 310 (5752), 1313-1317.

Sigman, D.M., Boyle, E.A., 2000. Glacial/interglacial variations in atmospheric carbon dioxide. Nature 407 (6806), 859-869.

Sigman, D.M., de Boer, A.M., Haug, G.H., 2007. In: Schmittner, A., Chiang, J.C.H., Hemming, S.R. (Eds.), Ocean Circulation: Mechanisms and Impacts. American Geophysical Union, Washington, DC, pp. 335-349.

Sikes, E., 2012. Radiocarbon in deep water in the Southwest Pacific and Southern Ocean since the last glacial maximum. Quat. Int. 279-280, 450.

Skinner, L.C., Fallon, S., Waelbroeck, C., Michel, E., Barker, S., 2010. Ventilation of the deep Southern Ocean and deglacial $\mathrm{CO}_{2}$ rise. Science 328 (5982), 1147-1151.

Skinner, L. 2012. Uncapping the Southern Ocean: evidence for a Southern Ocean 'physical/dynamical barrier'and its role in glacial-interglacial CO2 variability. Quat. Int. 279, 454.

Smith, H.J., Fischer, H., Wahlen, M., Mastroianni, D., Deck, B., 1999. Dual modes of the carbon cycle since the last glacial maximum. Nature 400 (6741), 248-250.

Spero, H.J., Lea, D.W., 2002. The cause of carbon isotope minimum events on glacial terminations. Science 296 (5567), 522-525.

Stephens, B.B., Keeling, R.F., 2000. The influence of Antarctic sea ice on glacial-interglacial CO 2 variations. Nature 404 (6774), 171-174.

Stocker, T.F., Johnsen, S.J., 2003. A minimum thermodynamic model for the bipolar seesaw. Paleoceanography $18(4), 1087$.

Stocker, T.F., Mysak, L.A., Wright, D.G., 1992. A zonally averaged, coupled oceanatmosphere model for paleoclimate studies. J. Clim. 5 (8), 773-797.

Stuiver, M., Reimer, J., 1993. Extended 14C data base and revised CALIB 3.014 C age calibration program. Radiocarbon 35, 215-230.
Tiedemann, R., Sarnthein, M., Stein, R., 1989. In: Ruddiman, W.F., Sarnthein, M. (Eds.), Proc. ODP Sci. Res, vol. 108, pp. 241-277.

Tjallingii, R., Röhl, U., Kölling, M., Bickert, T., 2007. Influence of the water content on X-ray fluorescence core-scanning measurements in soft marine sediments Geochemistry. Geophys. Geosystems 8 (2).

Toggweiler, J.R., Russell, J.L., Carson, S.R., 2006. Midlatitudewesterlies, atmospheric CO2, and climate change during the ice ages. Paleoceanography 21 (2).

Toggweiler, J.R., Russell, J., 2008. Ocean circulation in a warming climate. Nature 451 (7176), 286-288.

Tribovillard, N., Algeo, T.J., Lyons, T., Riboulleau, A., 2006. Trace metals as paleoredox and paleoproductivity proxies: an update. Chem. Geology 232 (1), 12-32.

Wang, X., Auler, A.S., Edwards, R.L., Cheng, H., Ito, E., Wang, Y., Kong, X., Solheid, M., 2007. Millennial-scale precipitation changes in southern Brazil over the past 90,000 years. Geophys. Res. Lett. 34 (23).

Watson, A.J., NaveiraGarabato, A.C., 2006. The role of Southern Ocean mixing and upwelling in glacial-interglacial atmospheric CO2 change. Tellus B 58 (1) $73-87$.

Wei, G., Liu, Y., Li, X., Chen, M., Wei, W., 2003. High-resolution elemental records from the South China Sea and their paleoproductivity implications. Paleoceanography 18 (2).

Weltje, G.J., Tjallingii, R., 2008. Calibration of XRF core scanners for quantitative geochemical logging of sediment cores: theory and application Earth and Planetary. Sci. Lett. 274 (3), 423-438.

Wu, L., Wang, R., Xiao, W., Ge, S., Chen, Z., 2015. High resolution age model of late quaternary mouth fan at Prydz trough. East. Antarct. Mar. Geol. Quat. Geol. 35 (3), 197-208,

Zhang, X., Lohmann, G., Knorr, G., Xu, X., 2013. Different ocean states and transient characteristics in Last Glacial Maximum simulations and implications for deglaciation. Clim. Past. 9 (5), 2319-2333. 